\title{
DEMAND FOR ENVIRONMENTALLY FRIENDLY VEHICLES: A REVIEW AND NEW EVIDENCE
}

\begin{abstract}
Although the need for more environmentally friendly vehicles was recognised some decades ago, this new market has yet not established itself. It is necessary to study consumer behaviour to ascertain when people would purchase hybrid or electric vehicles rather than conventional ones. An in-depth review of the state-of-the-art has identified existing deficiencies and these are addressed in this paper, proposing a new approach that is applied to the case of Santander in Spain. Emphasis is placed on the role of citizens in researching the local market and their requirements with respect to such vehicles; our model assumes variability in user preferences, an utmost requirement as concluded from the literature review. Results suggest that the highest demand for cleaner vehicles would be achieved in two ways: firstly, by penalizing conventional vehicles in terms of costs $/ \mathrm{km}$; secondly, by providing incentives directed to lower the purchasing price of hybrid and electric vehicles. Finally, as demand becomes more elastic, the preferred strategy should firstly focus on hybrid vehicles.
\end{abstract}

Keywords: electric vehicles, stated preference, mixed logit, heterogeneity

\section{Contributions/Highlights}

- Focus on the local framework through a debate among consumers in focus group sessions.

- Heterogeneity is addressed in various forms.

- Insights are provided into the dilemma of 'negative versus positive incentives'.

- Clear policy implications are drawn. 


\section{Introduction}

In spite of the higher environmental sustainability offered by electric motors when they are powered by low-emitting electricity (Tessum et al. 2014), sales of alternative vehicles are still scarce. The first studies on the purchase of hybrid (HVs) and electric vehicles (EVs), predicted the future availability of revealed preference (RP) data that would allow comparing the insights based on stated preference (SP) data. However, such situation is still future more than present. In the case of Spain, the greater proportion of new vehicle sales is currently taken up by hybrids, with a very weak market for electric cars (i.e. about $1.5 \%$ of all cars are currently hybrid and less than $0.1 \%$ of all car sales are electric vehicles).

The automobile industry continues striving to improve their efficiency so that cleaner vehicles become more attractive (Nunes and Bennett 2010; Zapata and Nieuwenhuis 2010). This coincides with the goals of governments and local administrations interested in designing a strategy to fulfil long-term emission targets. But the people have the last word: each citizen makes frequent transport and mobility related choices. Purchasing a vehicle is one of these choices and has a direct effect on the above common goal of industry and government, making the role of the consumer a key element in the process of change. For this reason, we are interested in examining the behaviour of consumers when faced with purchasing a new vehicle for their personal use.

In recent years the literature has contributed much to the knowledge about the factors affecting car purchase choices and a general conclusion can be drawn: results are very diverse, sometimes even opposed, but at the same time the methodological contributions are wide. The complexity of the issue is such that restrictive approaches will fail to consider taste heterogeneity that is a key characteristic of the population under study.

On the other hand, the diverse conclusions that many research studies have reached might also be a consequence of different social and economic contexts experienced by the populations studied in each case. Unfortunately, not much research has considered the citizens' household, cultural and purchasing backgrounds, which should be incorporated from the very start in any demand study. This is particularly important in the case of new products, since there is high uncertainty about their effects on consumers' perception, preferences and demand.

This research aims to overcome previous deficiencies detected in the literature and to provide a new perspective that, from the start, considers the behaviour and opinions of citizens (in this case from Santander, Spain). In fact, the first step in our methodology was designed to fill a gap identified by Rezvani et al. (2015): the need to understand consumers' preferences through group discussions. Actually, one of the contributions of our approach is the citizen involvement in focus group (FG) sessions that helped to uncover many aspects that potential buyers considered when faced with the hypothetical situation of choosing among a conventional, hybrid or fully electric vehicle. A second methodological contribution was in the modelling, using stated choice (SC) data, where we removed some constraints assumed by most previous research (e.g. van Rijnsoever et al. (2013)), allowing for different causes of heterogeneity in the sample.

The rest of the paper is organised as follows. In section 2, we discuss the state of knowledge on car purchase choices and the factors that have been shown to influence preferences for cleaner alternatives. At the end of this section we enumerate some contributions towards solving many of the literature's current deficiencies. Section 3 presents the proposed methodology for modelling vehicle-purchasing choice along with an analysis of the explanatory variables within the choice process as applied to the city of Santander. Section 4 computes the demand elasticity of each type of vehicle with respect to the influential variables considered in the choice process. Section 5 
describes distintos escenarios de demanda obtenidos a partir del modelo estimado and section 6 summarises our main conclusions.

\section{Review of Literature}

Initial research on alternative fuel vehicles was conducted by Brownstone et al. (1996), Gould \& Golob (1998) and Kurani et al. (1996), and took place after the oil crisis that unfolded in the 1970s. The increased awareness about the scarcity and price of fossil fuels provoked industry in North America to work on the development of more efficient engines and motors. Cleaner vehicles based on renewable energy were proposed and consumers' responses to this new market scenario became a focus of research (Beggs et al., 1981; Calfee, 1985).

\subsection{Technical issues}

An extensive literature is available about motor technology and mechanics, and the potential contribution that these could make to reduce emissions (Ahn et al., 2008; Karplus et al., 2010; Musti \& Kockelman, 2011; Shin et al., 2012). There is no doubt that the technical specifications of alternative fuel vehicles have an effect on consumers' choices. The set of attributes and alternatives considered by research studies concerned with understanding the demand for alternatively powered vehicles is large and diverse. In the case of engines/motors, apart from conventional petrol, completely electric and hybrid vehicles, different fuels have also been considered as alternatives, for example, liquid propane gas (Dagsvik et al., 2002) and hydrogen fuel cell vehicles (Horne et al., 2005; Mau et al., 2008; Struben \& Sterman, 2008). Brownstone et al. (1996) actually considered four types of fuels: petrol, compressed natural gas, methanol and electric.

In relation to vehicle size and type, Choo \& Mokhtarian (2004) considered luxury cars, sport vehicles and minivans, while Adler et al. (2003); Axsen et al. (2009) and Paul et al. (2011) established an ample range of alternative sizes and typologies. McCarthy \& Tay (1998) also considered the brand, length of the vehicle and presence of airbags as further explanatory variables. Other attributes included in the demand for alternative fuel vehicles have been maintenance costs (Ahn et al., 2008), vehicle warranty (Mau et al., 2008) and luggage space (Brownstone et al., 1996).

Other types of technical specifications, such as acceleration or speed, are less commonly found in the literature. Speed was considered by Brownstone et al. (2000) and Dagsvik et al. (2002); and acceleration by Brownstone et al. (2000) and Ewing \& Sarigöllü (1998). Other authors, such as Axsen et al. (2009); Bolduc et al. (2008) and Horne et al. (2005) included horsepower among the group of attributes to explain vehicle choice.

Consumption (of liquid fuel and electricity) is another attribute considered by the majority of case studies. Indeed, the cost of fuel has also shown to be important in several studies (Musti \& Kockelman, 2011; Turrentine \& Kurani, 2007). Ewing and Sarigöllü (1998) stand out in that to simplify the choice process they considered fuel consumption together with parking. On another hand, together with consumption, manufacturers tend to inform on the type and amount of gas emissions. This aspect has been considered by, for instance, Hidrue et al. (2011) and Taylor et al. (2013).

However, in terms of technical features, the limited range of electric vehicles is clearly one of the major barriers for consumers according to our literature review (Stark et al. 2015). In fact, Daziano \& Chiew (2012; 2013) called "driving range anxiety" the preoccupation experienced by drivers due to the limitations of this EV attribute and estimated willingness-to-pay (WTP) for improved 
batteries with longer ranges. Nevertheless, this limitation has been found less influential depending on the number of vehicles available, as several authors have found that the range is not such an issue for households who already own a petrol vehicle with greater autonomy and obtained higher willingness to buy an EV (Bühler et al., 2014; Kurani et al., 1996).

Various actions proposed in the literature should be considered to face the concern about the limited range of EV, making cleaner alternatives to the petrol car more appealing. For example, many authors have suggested the development of recharging infrastructure; the explanatory value of fuel and recharging station availability has been measured by Bolduc et al. (2008); Horne et al. (2005) and Mau et al. (2008). Some studies have concluded that the possibility of having household or workplace recharging points would guarantee growth in the EV market since the range anxiety would lessen (Bühler et al., 2014; Lin \& Greene, 2010). The location and availability of recharging points has also been addressed by Jensen et al. (2014) in a novel SP experiment incorporating actual use of EV by respondents in Denmark, and by Axsen \& Kurani (2012), who analysed access to home recharging facilities in San Diego.

The effect of recharging times has also been estimated in the literature (Ewing \& Sarigöllü, 1998; Hidrue et al., 2011); however, Greaves et al. (2014) found that such aspect does not affect the feasibility of EV for general travel patterns where the vehicle is parked most of the time. Ito et al. (2013) found that an efficient scenario would be to have battery-exchange stations when electric sales were over a certain threshold (5.6\%) of the total market.

Now, although the above features are important from the perspective of vehicle usage, the purchase decision may be determined by the consumer's travel patterns. Indeed, some authors have explicitly focused on how the travel needs and vehicle usage determine consumer behaviour. For example, Greaves et al. (2014) and Kölbl et al. (2013) concluded that EV and specifically their limited ranges, are actually feasible for day-to-day driving given actual travel patterns. It should be mentioned that, in any case, the majority of studies concerned with factors affecting purchase choice considered variables that directly or indirectly informed on vehicle usage.

Apart from the specific characteristics of the product the high price of these new vehicles is considered to be one of the main causes of their low demand (Lebeau et al., 2012). The research led by Dagsvik et al. (2002) highlighted the relevance of the initial purchase price and the range. Similarly, Hidrue et al. (2011) found that potential buyers opted for cleaner alternatives only if this meant a cost saving over a conventional vehicle. They also found that, apart from the range anxiety and long charging time, the most important variable for drivers was the price. In fact, Karplus et al. (2010) defend the idea that, together with battery costs, vehicle costs should drop to guarantee market penetration. They state that a 15\% higher price for an EV over an internal combustion vehicle is reasonable, but an $80 \%$ higher cost is not, unless there are really strong policies aimed to deter use of fossil fuels.

\subsection{Understanding the potential of political strategies: Incentives}

All things considered, many studies have measured the effect of applying purchase incentives for EV sales (Adler et al. 2003; Horne et al., 2005; Potoglou \& Kanaroglou, 2007; Tanaka et al., 2014); these are generally regarded as the most efficient type of incentive to stimulate demand for cleaner vehicles (Ewing \& Sarigöllü, 1998; Jones et al., 2013; Shin et al., 2012). In fact, even private discount rates of around 20-25\%, have been discussed (Mau et al., 2008).

Other kinds of incentives have also been evaluated. The most common ones are access to fast lanes or high occupancy vehicle (HOV) lanes (Diamond, 2009; Horne et al., 2005; Taylor et al., 2013) and parking discounts (Adler et al., 2003; Potoglou \& Kanaroglou, 2007). For example, Adler 
et al. (2003) found that tax-reductions and parking incentives appeared to be the most efficient drivers for encouraging EV market penetration. Diamond (2009) analysed the stimulant effect of access to HOV lanes, showing that this policy may not have an impact on the market if travel times are not significantly improved too. Francisco and Tibor (2015) tested policy incentives such as a Park and Ride subscription and a one-year -ticket for public transportation in a study case in Austria. The authors found that these incentives had no significant impact on the adoption of EV. Gallagher \& Muehlegger (2011) considered the impact of fuel prices and tax incentives on the adoption of hybrid vehicles; they concluded that both the type and generosity of the incentives influenced purchase choice. Notwithstanding, Potoglou and Kanaroglou (2007) found that although purchase incentives had a significant positive impact, those applied to parking or access to fast lanes did not. This conclusion agrees with Diamond (2009), who notes that those incentives with highest impact are immediate ones, that is, those applied to the purchase price rather than those who are perceived over the long term. This result is supported by the research of Shin et al. (2012), who concluded that tax incentives were less powerful than price subsidies in the promotion of cleaner vehicles. Furthermore, both Shepherd et al. (2012) and Struben \& Sterman (2008) studied the promotion power of incentives in depth, highlighting the need to evaluate the continuous application of subsidies over a long enough time period to establish and stabilise the market.

Finally in terms of policy, a yet unanswered question is: are positive incentives more effective than negative incentives? That is, is it better to focus on positive incentives such as tax reductions for EVs and HVs, or in negative incentives such as tax increases for conventional vehicles? This paper attempts to respond this important question as well.

\subsection{Intangible factors associated with the willingness to purchase alternative-fuel vehicles}

Some authors have identified other causes that explain the lack of success of alternative fuel vehicles. Jaffe \& Stavins (1994) identified three factors in the field of energy - efficient investments: information, principal-agent problem and unobserved costs. The lack of information about new alternatives was regarded as an important barrier because usually is costly for consumers to learn about new technologies and innovations. The principal - agent problem can arise when the efficient energy decisions are made by different agents than those who pay the cost (e.g. landlords and renters), whereas the unobserved costs may appear in situations in which artificially low energy prices lead to a disinterest in more efficient solutions. Struben and Sterman (2008) developed a behavioural model to understand the spread of these new technologies; they support the idea that providing information is one way to increase uptake of alternative fuel vehicles, and also indicated that word of mouth and social exposure encouraged the purchase of new products.

As the lack of adequate information increases the aversion to purchase new alternatives, initiatives have been proposed worldwide to provide access to hybrid and electric vehicles during a period. The idea is to measure the impact that actual use has on the willingness to buy new alternatives. Gould \& Golob (1998) found that people who had been users of an EV for two weeks became much more positive about their environmental effects. This result led them to suggest the promotion of public access to demonstrations and tests of new technology vehicles, partly to also face the great suspicion found about the long-term costs of fuel or batteries for each type of vehicle. Turrentine and Kurani (2007) and Kurani et al. (1996) emphasised the importance of providing adequate information when launching a new technology product, so that potential buyers could form a realistic opinion about its attributes and the benefits it might bring. In their research, a video demonstrating how to use and recharge an EV accompanied a household survey; they found significant WTP for increased autonomy under certain activity patterns and uses of the 
private car, and cautioned that the market for EV could shrink if there was persistent publicity about their low range and longer recharging times in comparison with petrol engines.

On another vein, Jensen et al. $(2013 ; 2014)$ performed an interesting experiment. They allowed people to use an electric vehicle for three months with the aim to discover if there was any change in attitudes or preferences before and after the real experience. The authors found that the individual preferences changed significatively after use an EV and that the driving range was a critical factor. As the years have passed, research has been conducted on the impact of public and private initiatives giving access to hybrid and electric cars during a period of several weeks or months. Regan et al. (2013) informed that drivers adapted their needs to the possibilities of the car (i.e. finding an increasing number of short trips and charging batteries overnight at home), and confirmed the importance of promoting household recharging facilities. The range preference was relaxed after a 3-months trial in the research conducted by Franke \& Krems (2013), who found that range needs and preferences were more accurately related after the real experience. Furthermore, as it occurs with any new product, the greatest the market penetration, the highest the value is placed on it. Mau et al. (2008) and Axsen et al. (2009) studied this phenomenon in the case of cleaner vehicles. The authors defined as "neighbour effect" the greater value and probability to buy EV when these vehicles are familiar to potential buyers due to the increasing presence of alternative cars.

Some of the factors already mentioned can indirectly be connected with attitudes. The inclusion of cognitive psychology in econometric modelling, through attitudes, has been found to shed some light on the behaviour towards purchasing cleaner vehicles and has introduced new sources of heterogeneity. This perspective requires the specification of latent factors to describe the subjective nature of attitudes. These are measured through observable indicators that, in the literature, have been associated with issues such as: (i) the symbolism involved in the purchase of a recently launched vehicle; (ii) saving money; (iii) the opposition towards fossil fuel producers; (iv) the possession of the latest technology (Heffner et al., 2007); (v) safety perceptions and status seeking (Jensen et al., 2013). Notwithstanding, the major focus has been environmental awareness and the preoccupation about emissions. In particular, Daziano and Bolduc (2013) found that women were more worried about the environment, as were elderly people, more highly educated people and users of public transport, and that such preoccupation had a positive impact on the probability of buying cleaner vehicles. On the other hand, several studies argue that environmental awareness is not as important as range anxiety or high purchase prices (Bolduc et al., 2008; Gould \& Golob, 1998; Kurani et al., 1996).

In the case of organizations/companies, the uptake of EV has been found related with nontangible factors such as their public image, but may be also affected by other traditional aspects, such as government incentives and pollution reduction (Sierzchula, 2014).

The transitions theory and the niche management approach are explored by Steinhilber et al. (2013). These frameworks try to integrate the results achieved in policy practice explaining why different technologies have been successful or not. The data used by the authors was obtained from interviews with important agents in the automotive and public sectors. The results showed that the penetration of EV is hindered by several barriers including the limitations of the current technology, the lack of a good infrastructure and the inadequacy of the regulation. The authors recommended changing the regulation in order to make the innovations more attractive to both, producers and consumers.

Finally, it should also be mentioned that even if new vehicles are not the most attractive option to buyers, penalizing the use of fosil-fuel vehicles could stimulate demand towards more sustainable alternatives. This is considered by many authors as the factor that could have the greatest impact 
on purchase choice. Ewing and Sarigöllü (1998) mention taxes on polluting vehicles, while Daziano and Bolduc (2013) highlight the role of fuel taxes and road tolls as ways to encourage purchasing an EV.

\subsection{Approaches to study the demand for cleaner vehicles}

A wide variety of methods has been proposed to predict the demand for alternative fuel vehicles. For instance, binomial and multinomial logit (MNL) models were the choice of Ewing and Sarigöllü (1998, 2000); Brownstone et al. (2000), Struben and Sterman (2008) and Musti and Kockelman (2011). On the other hand, McCarthy and Tay (1998), Adler et al. (2003), Potoglou and Kanaraglou (2007), and Lin and Greene (2010) have used nested logit (NL) models, allowing for correlation among certain alternatives. Dagsvik et al. (2002) estimated a ranked ordered logit model and Daziano and Chiew (2013) proposed a more flexible probit model with a Bayesian estimator. The presence of heterogeneity in preferences has been considered by Brownstone \& Train (1999) and Brownstone et al. (2000) through the use of mixed logit (ML) models, and by Ziegler (2012) with a multinomial probit model. Finally, Bolduc et al. (2008), and Daziano and Bolduc (2013) proposed hybrid choice models (HCM), including latent variables, for the purchase choice. Also latent variables, together with stated preferences were originally gathered by Jensen et al. (2014) in a panel survey to test the change in preferences after a real experience with the new battery electric vehicles.

Other approaches proposed in the literature for modelling the choice process associated with buying a new car have been ordinary least squares (OLS) and weighted least squares (Diamond, 2009; Dimitropoulos et al., 2013), as well as energy-economy models allowing to simulate the costs and effects of a given policy (Horne et al., 2005; Mau et al., 2008; Axsen et al., 2009). Choo and Mokhtarian (2004) applied ANOVA analysis and $\chi^{2}$ tests to determine the differences in choice according to different attitudes and social demographic factors.

Considering the demand target, the literature has examined a rich range of potential buyers. Most research has centred on the household decision to buy a new vehicle (Brownstone et al., 1996; Turrentine and Kurani, 2007; Lin and Greene, 2010; Daziano and Bolduc, 2013; Musti and Kockelman, 2011); Potoglou and Kanaroglou (2007) introduced household characteristics such as income, dwelling size, education standard, gender and age, and Gao \& Kitirattragarn (2008) estimated the preferences of taxi drivers for purchasing hybrid-electric vehicles. On the other hand, organizations and companies were the target group of Sierzchula (2014), whilst Jones et al. (2013) focused on the potential market of electric motorcycles in Hanoi, Vietnam.

Some authors have obtained consumer profiles, that is, the characteristics of the people more likely to purchase hybrid or electric cars. The literature shows contradicting results in this sense, probably caused by cultural, social and economic differences describing the diverse societies analysed. For example, age appears to be a discordant aspect (Ziegler, 2012); there is evidence that age has a negative effect on the willingness to purchase cleaner vehicles (Potoglou \& Kanaroglou 2007; Ewing \& Sarigöllü 1998), but also that the influence is positive (Musti \& Kockelman, 2011). Similarly happens with gender as some authors found that females show a higher probability of buying cleaner vehicles (Dagsvik et al., 2002; McCarthy \& Tay, 1998), whilst Ziegler (2012) found the opposite. McCarthy \& Tay (1998) also identified lower income households, non-white buyers, and drivers living in more densely populated areas as more prone to buying an EV. On the contrary, several authors found evidence that higher educated people are more likely to choose cleaner alternatives (He, et al., 2012; Hidrue et al., 2011; Potoglou \& Kanaroglou, 2007). 
Plötz et al. (2014) recently characterised early adopters as having both electric and fuel cars available and being middle-aged male workers with a technical education, living in rural areas or in the outskirts of cities, who travel long distances to commute, thereby being willing to avoid kilometer penalizations applied to conventional vehicles. In contrast, (Tamor et al. 2015) Hoen \& Koetse (2014) and Li et al. (2013) found that preferences for EV decreased as the annual distance driven increased.

Various authors have reviewed the literature on the demand for alternatives to conventional vehicles. Hidrue et al. (2011), Daziano and Chiew (2012) and Daziano and Bolduc (2013) discuss the attributes considered in different case studies to model purchase choice. Also, an interesting meta-analysis has been done by Dimitropoulos, et al. (2013), focusing on the approaches proposed to measure the WTP for driving range. Finally, for a detailed description of the selection of attributes, methods and perspectives in the specific research of EV adoption, the review done by Rezvani et al. (2015) is very extensive, particularly in the narrative about emotional and attitudinal factors.

\subsection{Literature summary and research proposal}

The above review of the international literature provides several interesting conclusions. The attributes that are most frequently considered in EV choice are motor and vehicle type, consumption, range, speed, acceleration and emissions. Range, accessibility of fuel, recharging conditions and price have all turned out to be significant in various studies. Nevertheless, the purchase decision is not a function of technical variables only. Choice variability is ever present in the literature and a wide range of causes of heterogeneity have been identified and measured through different methods. Overall, differences in preferences have been shown to depend on many aspects: location, available and/or provided information, the experience of respondents, the group of attributes considered, the questionnaire design and the model specification chosen.

Methods proposed to treat heterogeneity are diverse. One of the most widely applied is the introduction of factors that describe the choice context and may have an influence on the final decision (Brownstone et al., 1996; McCarthy and Tay, 1998; Musti and Kockelman, 2011; Paul et al., 2011). These can be socioeconomic variables, personality and lifestyle characteristics or mobility aspects (Choo and Mokhtarian, 2004), travel patterns (Ewing and Sarigöllü, 1998) and economic and cultural circumstances, as highlighted by Tanaka et al. (2014) in the comparison of several US states with Japan. Consequently, there is a need for more flexible modelling in order to allow for a correct treatment of the intrinsic variability in tastes and preferences that characterize this type of choices (Ziegler, 2012).

In an attempt to better adjust models to the real world situation, we propose a methodology to determine the purchase decision as a function of a set of variables uncovered in citizen participation sessions, together with the consideration of various potential sources of heterogeneity. The approach places relevance on the local context (i.e. economic situation and cultural lifestyle), considers citizen participation (through a direct exploration of their preoccupations and influential factors), and proposes an advanced modelling approach flexible enough to consider several sources of variability.

Our research work was applied to the city of Santander (Spain). The implementation of the proposed approach led to insights on the policies that would cause the highest positive impact of a shift to cleaner vehicles. Our work also intended to bring light about the dilemma raised by Rezvani et al. (2015), whether policies should focus on promoting new alternatives or in preventing the purchase of conventional ones. 


\section{Proposed Methodology}

This section is concerned with explaining the process of modelling vehicle purchase choice among three types of engines/motors currently available in the market: internal combustion, hybrid (pluginable and non - pluginable) and fully electric.

\subsection{Focus groups}

Each individual region may be affected by intrinsic conditioning factors and may be subject to different levels of information about new products; this may also affect the way in which certain aspects are perceived. It might also cause differences with respect to other regions, urban centres or countries, as concluded by Dimitropoulos et al. (2013) after comparing results from nine different countries. Therefore, the first step in this research was to hold focus group (FG) sessions to uncover the a priori qualitative perception of the people of Santander about purchasing hybrid or electric vehicles (EV).

Rea and Parker (2014) proporcionaron una metodología para el correcto diseño y desarrollo de los FG: identificación del objetivo del FG, identificación de participantes, establecimiento del número de FG necesarios, elección del lugar para realizarlo y establecimiento del día y hora del FG.

The main aim of these sessions was to discover which variables were consciously considered by citizens in relation to purchasing an EV. The process allowed to uncover existing worries and barriers, as well as some advantages felt by potential buyers (Ibeas et al., 2011). Se organizaron dos FG con vecinos de la ciudad de Santander. Ambos grupos estuvieron formados por 10 miembros reclutados a partir de las organizaciones vecinales de la ciudad. Se eligió realizar dos FG con el objetivo de representar a todas las asociaciones. En ambos grupos se les facilitó a los participantes información sobre los vehículos eléctricos, se les preguntó sobre las principales ventajas y desventajas de este tipo de vehículos así como sobre su disposición al cambio y sobre las medidas que tomarían para fomentar el uso del vehículo eléctrico. Los FG fueron conducidos por una persona experta en participación ciudadana y movilidad sostenible en las instalaciones de la Universidad de Cantabria. Ambos FG se realizaron en dos días laborables consecutivos a las 19 horas para asegurar que las personas que tuvieran que trabajar pudieran asistir a la sesión.

The sessions involved discussions about the pros and cons of electric/hybrid vehicles. Advantages were medium/long-term economic and environmental savings; although a lack of detailed information was evident among people. Apart from the initial costs, the disadvantages included the preoccupation with the limited range provided by EV and its resulting uncertainty, together with - as far as they were aware - the lack of a recharging network. Access to recharging stations was not only worrisome for urban journeys, but even more so for long distance trips where people feared having little or no knowledge about available infrastructure. FG members coincided on the need for more information about EV and their features, but assumed that EV were not currently competitive with petrol or diesel-powered vehicles. They also expressed the view that any changeover to cleaner vehicles would be a gradual process, starting with an increasing demand for hybrids to be later followed up by full EV (and these would be used initially mainly in urban areas). FG members highlighted the need for information campaigns and indicated that public institutions should provide an initial example by adopting these kinds of vehicles. Finally, they suggested that providing incentives to reduce their weaknesses should be the way to promote this new market.

Few studies reported in the literature have used FG (Ewing and Sarigöllü, 1998; Dagsvik et al., 2002; Hidrue et al., 2011). Notwithstanding, in spite of the results coming from these sessions in 
the majority of cases the final survey forms were designed on the basis of pre-defined variables supported by the literature, dándole menos importancia a los resultados obtenidos de los FG.

In our study, instead, the variables used in the subsequent survey were defined during the discussions held at the FG sessions. We assumed that the attributes and considerations that verbally arose during the FG were those being consciously considered by individuals when comparing alternatives. The FG meetings also allowed us to understand that individuals were not able to evaluate a large number of variables simultaneously, unless the discussion was specifically geared to stimulate the consideration of new factors. By incorporating this knowledge, we expect that our models should reflect local individual perceptions better and eventually allow us to design efficient strategies for answering the needs of our specific setting.

\subsection{Data collection}

Ewing and Sarigöllü (1998) predicted the future availability of revealed preference (RP) data to validate the results of predictions made by models based on stated preference (SP) experiments. However, this prediction has not yet come true, at least in Spain. As Daziano and Chiew (2013) indicate, access to RP data is still limited due to the low sales of alternative vehicles. Therefore, our research involved the design of an SP survey to recreate different hypothetical choice frameworks based on the current supply of EV. The SP surveys are particularly useful in choice situations in which the respondents have little experience with EV.

After a pilot test, the final survey was applied to 181 households seleccionados aleatoriamente. Los Resultados de un modelo preliminar estimado con los datos de la encuesta piloto aseguraron que todos los parámetros podían estimarse con un nivel de confianza superior al $95 \%$ con al menos 100 encuestas. We specified that a household member with the decision power to buy a vehicle should answer the survey. Two different survey forms were designed: one contained specifications about medium sized vehicles and the other about large vehicles, so that data was more precisely customised to the needs of each respondent and that choice scenarios resembled the preoccupations of potential buyers more realistically. Respondents had to answer one or the other questionnaire depending on the type of vehicle they were thinking of acquiring in the future.

The survey followed an efficient design based on the RSC (Relabelling, Swapping, Cycling) algorithm and presented eight choice situations (scenarios) to each respondent (Rose \& Bliemer, 2009). RSC es un algoritmo iterativo de búsqueda de diseños experimentales basado en columnas. Las columnas del diseño experimental se crean en cada iteración a partir de tres criterios de tratamiento de los niveles de los atributos: Relabeling, Swapping and Cycling (Hensher et al. 2015). Para cada diseño obtenido se evalúa su indicador de D-Error escogiéndose finalmente aquel diseño con el mínimo D-Error. Por lo tanto, se escoge el diseño que permite estimar los parámetros del modelo de elección discreta con el mínimo error estándar posible. Este tipo de diseño tiene ventajas respecto a los diseños ortogonales ya que permite estimar los modelos con un menor número de encuestas y presentando parámetros con un mayor nivel de significatividad.

In each scenario, respondents were asked to choose the alternative they would buy, among: (i) a car with an internal combustion (C) engine, (ii) a petrol-battery hybrid (H), or (iii) a completely electric $(E)$ vehicle. The hybrid vehicle alternative considered both, the pluginable and non pluginable types currently available on the market. Table 1 shows the variables considered in the experiment for each vehicle type as a result of the FG work. En la table 2 pueden consultarse los niveles utilizados para el caso de los vehículos de medio tamaño. 
[Table 1. Attributes describing the alternatives in the SP choice experiment]

In the survey form, the price was presented as the amount of money that finally had to be paid (i.e. after applying the discount as a purchase incentive) for each type of vehicle. A través de la encuesta piloto se comprobó que de esta forma los encuestados comprendían mejor la encuesta y podían comparar de forma más ágil las alternativas.

[Table 2. Attributes levels in the SP choice experiment for medium sized vehicles]

As well as choosing an alternative in each scenario, individuals were also asked to answer a series of questions about their household and the characteristics and use made of the cars available to its members. Table 3 summarises the answers.

Most respondents were men (64\%) and their age distribution showed that more than $70 \%$ had between 25 and 64 years old. Also, more than $70 \%$ of households were made up of one or two members and the average monthly household income was less than $€ 2,500$. On the other hand, $80 \%$ of households interviewed owned only one car and $12 \%$ had two (a little over $3 \%$ of the households had three or more cars). De cara a asegurar la representatividad de la muestra, se realizó un Pearson's chi squared test en las variables: número de miembros del hogar y número de vehículos del hogar. En ambos casos no pudo rechazarse la hipótesis nula de no diferencia entre las distribuciones de la población y la muestra por lo que hay evidencia de que ésta última es representativa de la población. La tasa de respuesta de la encuesta fue de 0.8. En caso de no recibir respuesta de algún hogar se procuró su sustitución con el hogar de la vivienda más próxima posible.

[Table 3. Distribution of observations in the sample]

While quite a considerable $22 \%$ did not know if there were any recharging points in the area around their home, around $70 \%$ confirmed that there were none. When asked about their next purchase of a new vehicle only $10 \%$ said they would do it within the next three years and $36 \%$ did not know. When asked about the size of car they would buy, $71 \%$ declared it would be a mediumurban sized car.

A whole section of the survey was related with the use and conditions of the first household's current vehicle that would be replaced. Around 39\% replied that it had a garage located at home, followed by $35 \%$ replying that it used unreserved street parking. The fact that $70 \%$ declared that this vehicle was required for mostly urban or mixed urban-interurban usage is striking, along with the report that over $60 \%$ of cases reported a daily frequency of use. This is interesting additional information because it addresses the current situation, providing RP data that can help determining the reasons behind systematic variations in the perception of some attributes considered in the SP experiment. Therefore, as in the case of Brownstone et al. (1996), we do not model SP and RP data together, but rather use a SP choice experiment supported by RP data about the use and ownership of the households' current vehicles.

\subsection{Modelling purchase choice}

Probably due to the novelty of the product and because the information provided about its characteristics is generally heterogeneous or limited, a great variability in consumer preferences 
exists as was concluded from the literature review. For these reasons, a mixed logit (ML) discrete choice model (Train, 2009) was proposed to explain the purchase choice among the three alternatives: gasoline-powered, hybrid and electric vehicles.

ML models are fairly complex and may contain different forms of randomness (Greene et al., 2006) to relax the less realistic hypotheses assumed in simpler choice models such as the MNL or $\mathrm{NL}$, in relation to caveats such as independence among alternatives, heteroscedasticity and taste variations (Ortúzar \& Willumsen, 2011, Ch. 7 and 8).

Correlation between alternatives and heterogeneity in perceptions need to be considered to adapt future marketing campaigns to the diverse preferences found among the population. The basic utility specification of our ML model was as follows:

$$
U_{i q t}=\sum_{k}\left(\beta_{k q} \cdot x_{k i q t}\right)+\theta_{i} \cdot E_{i q}+\varepsilon_{i q t}
$$

where $U_{\text {iqt }}$ is the utility of alternative $i$ for individual $q$ in choice situation $t ; x_{k i q t}$ is the value of attribute $k$ of alternative $i$ for individual $q$ in choice situation $t ; \beta_{k q}$ is the value of its parameter for individual $q$ and $\varepsilon_{i q t}$ is a random error term, which is assumed to be independent and identically distributed (IID) extreme value type I. $E_{i q}$ are alternative specific random individual effects, that is, the variability induced by the alternatives themselves that is not considered by the attributes in the model (Greene, 2007). For the model to explicitly explain this variation, the effect is represented by $\theta_{i}$, which is the standard deviation estimated by the model, and made explicit for convenience.

The parameters $\beta_{q}$ represent the importance that individual $q$ places on the attribute to which the parameter is associated with and - in our specification - are made up of various elements:

$$
\beta_{q}=\bar{\beta}+\beta_{F} \cdot F_{q}+\Gamma \cdot v_{q}=\bar{\beta}+\beta_{F} \cdot F_{q}+\eta_{q}
$$

where $\bar{\beta}$ is the mean (population) parameter; $F_{q}$ are factors behind the systematic taste variation; $\beta_{F}$ are parameters to be estimated that weigh the effect of the $F_{q}$ factors on the mean parameter $\bar{\beta}$ (Ortúzar and Willumsen, 2011, page 279); $\eta_{q}$ distributes among individuals according to a random variable $v_{q}$ (generally assumed to distribute normal, lognormal, uniform or triangular) and $\Gamma$, represents the elements of the Cholesky matrix, which allow for correlation between random parameters (Train, 2009).

Equation (2) contains the diverse forms of randomness that can exist in the subject population and which may be considered in the specification of the ML model (Walker et al., 2007). On the one hand, the random distribution of the parameter allows each individual to value differently the importance of each attribute. If the stated importance does not show any randomness among the population, then the parameter is defined by its population average $\bar{\beta}$. On the other hand, the most general ML model also allows for correlation between those parameters showing significant randomness, given that this is another cause of variability in the perception of variables. This effect is controlled by the $\Gamma$ elements in the Cholesky matrix, which is a triangular matrix where the main diagonal elements represent the existing randomness in the perception of the associated variables, and those beneath the main diagonal report on the randomness due to correlation between parameters; that is, if a below-diagonal element is significant, it implies that there is correlation between the importance placed on the two variables associated with that element of the Cholesky matrix. Finally, the $F_{q}$ elements represent the group of factors that may have a 
systematic observable effect on the average importance of the attributes. These factors normally represent socio-economic or other conditioning characteristics present in the choice framework. They were introduced as interactions of the demographic variables with the attributes of the SP experimental design in the proposed model.

The unobserved components in equations (1) and (2) allow for correlation between the model parameters and relax the independence from irrelevant alternatives (IIA) constraint of the MNL model. Finally, given that eight choice scenarios were presented to each individual, the data was specified as a pseudo panel to consider the interdependence in the responses made by the same individual (Ortúzar and Willumsen, 2011, section 8.6.5).

The ML model can be estimated by simulated maximum likelihood. In this case, we used the NLOGIT software package and specified for 400 Halton points; the estimation results are presented in Table 4. En total se contó con 1448 observaciones dado que cada hogar contestó a 8 escenarios.

\subsection{Estimation results}

Los resultados señalan que, as other studies have concluded, the purchase price significantly affects the choice among the three alternatives. The incentive itself did not yield significant parameters although its amount was clearly indicated. So, it would appear that, independently of the incentive, buyers only considered the final price they have to pay. The importance of the price coincides with previous research and allows to confirm that one of the main barriers to purchase alternative fuel vehicles seems to be the price. Nevertheless, the importance of this attribute has a heterogeneous Normal distribution across the population. The reasons for this dispersion are revealed by the elements in the Cholesky matrix (Table 4); these suggest the existence of correlation between the importance of price and the range in the case of petrol-powered and electric vehicles.

[Table 4. Estimated parameters describing purchase choice]

Another technical characteristic included in the SP survey was the cost associated with the fuel or battery consumption. Although this does not have any bearing on the final choice of an EV, it does in the case of the other two options, where its perception is homogenous among the population. In addition to this, an interaction effect that proved significant was the consumption of the conventional car, which has an additional weight in the case of people who indicated that they planned to buy a new car within the next three years. This interesting result implies that the perception of the traditional vehicle's consumption is more negative for those households planning to renew their cars in the immediate future, reducing their willingness to purchase the currently most preferred option.

Interestingly, when the car is planned to be renewed in the long term (i.e. in more than five years), the utility of the hybrid vehicle increases (estimated parameter: 0.853 ). This result may be due to lack of confidence concerning the actual features of the new alternatives which, according to Turrentine and Kurani (2007), reside in the uncertainty about the long term costs of fuel and batteries. Given this result, it would appear that there could be a much higher future demand for hybrid vehicles and, as a consequence, marketing strategies might be better directed to the hybrid alternative first.

Regarding charging infrastructure, the model confirms that the availability of battery recharging points has a positive effect on the utility of EV. The discount in the cost of on-street parking is also an influential factor in favour of EV but not as much as the latter (estimated parameter: 1.437D-02 
versus 1.681 for recharging points). This result also supports previous research findings concluding that the immediacy of incentives has a higher impact on the sales of new cars than other measures, such as discounts in on-street parking, the benefits of which are perceived only in small quantities as time goes by (Potoglou \& Kanaroglou, 2007; Shin et al., 2012).

The term representing ignorance about the existence of battery recharging points in the surroundings of households clearly reduces the attractiveness of the electric alternative. This sign of the parameter is also consistent with previous findings about the negative effect, even barrier, which lack of information has on newer alternatives. In this case, it is the ignorance about the existence of a service network, which represents an uncertainty associated with the range anxiety (Daziano and Chiew, 2012; 2013) and which decreases the utility of the EV.

A final analysis of the results in Table 4 relates to the error components, $E C$, specified to account for unobservable variability in utility. Three nests were introduced in the model, one for each pair of alternatives, so that the presence of correlation between alternatives may be detected through the common variability in the error of the utilities. As shown in Table 4, the terms EC (Combustion - Hybrid) and EC (Hybrid - Electric) were significant. This suggests a common heterogeneity in the demand for the petrol and hybrid options, así como entre las alternativas vehículo híbrido y eléctrico. La modelización de este hecho es relevante de cara a que las tasas de sustitución simuladas entre las alternativas sean realistas.

El ajuste final del modelo fue bueno y claramente superior a la log - verosimilitud del modelo sin coeficientes (Pseudo $\mathrm{R}^{2}=0.54$ ) y de sólo constantes (Pseudo $\mathrm{R}^{2}=0.33$ ).

\section{Demand Elasticity for Each Type of Vehicle}

The model parameters take on a practical sense in the analysis of the demand elasticity for the three alternatives considered: conventional, hybrid and electric vehicles. The direct demand elasticity quantifies the variation in the demand of an alternative as a function of any attribute considered in its utility function. It is given by the following expression:

$$
E_{i i}=\frac{\partial P_{i q}}{\partial x_{i k q}} \cdot \frac{x_{i k q}}{P_{i q}}
$$

where $\mathrm{E}_{\mathrm{ii}}$ is the direct elasticity of the demand of alternative $i$ with respect to attribute $k$ for user $q$; $P_{i q}$ is the probability that user $q$ will choose alternative $i$; and $x_{i k q}$ is the value of attribute $k$ of alternative $i$ for user $q$.

The cross elasticity of demand quantifies the variation in the demand for an alternative due to the variation of a variable in the utility of a competing alternative:

$$
E_{i j}=\frac{\partial P_{i q}}{\partial x_{j k q}} \cdot \frac{x_{j k q}}{P_{i q}}
$$

where $E_{\mathrm{ij}}$ is the cross elasticity of demand for alternative $i$ with respect to attribute $k$ of alternative $j$ for user $q$.

The average demand elasticity values (calculated using sample enumeration, see Ortuzar and Willumsen, 2011, Ch. 9) from our model and sample of observations are shown in Table 5. Es importante considerar que un incremento en un $1 \%$ en algunas variables para las distintas 
alternativas presenta una magnitud diferente en términos absolutos (e.g. un incremento de un 1\% en range supone más kilómetros para el vehículo de combustión que para el vehículo eléctrico en términos absolutos).

[Table 5. Elasticities of demand for the three vehicle alternatives]

These results may be informative for the design of marketing strategies for alternative-fuel vehicles. Firstly, the direct elasticity of demand for the combustion vehicle with respect to all attributes that significantly influence its choice is smaller than one in absolute value; that is, a percentage point in the variation of each variable implies less than a percentage point in the variation of the demand for the non-sustainable alternative. This implies that the demand for the conventional vehicle is fairly inelastic. This result is consistent with the preference of respondents to purchase an internal combustion car and describes the present scenario.

Regarding direct price elasticities, Dagsvik et al. (2002) obtained similar values; however, in our case study the hybrid and electric vehicles obtained a purchase elasticity four times higher than the fuel-powered vehicle elasticity. Obviously, the time that has passed and the local conditions and market framework are possibly important causes for such divergence. In any case, it is important to remark that the demand of hybrid and electric technology to price is highly elastic ($2.230,-2.404)$ whereas the elasticity of demand for conventional vehicles is limited with regard to price variations (the direct elasticity is only -0.603).

The elasticity for the EV is also above one for the fuel consumption and the price of the conventional alternative, e.g. an increase of one percentage point in the cost of fuel would cause an average increase of $1.418 \%$ in the demand for EV. Furthermore, this same variable also has the largest effect after the price on the demand for the conventional vehicle, but in this case with a negative sign (-0.572), correctly meaning that less efficient engines or higher gasoline or diesel costs would imply a reduction in the demand for petrol-driven vehicles. In addition, fuel consumption also presents a high elasticity in the choice for hybrid vehicles (1.748). The conclusion from these results is that both, gasoline and diesel costs, are key variables in the demand for the three alternatives. This is consistent with evidence provided by other authors; for example, Graham-Rowe et al. (2012) concluded that an increase in liquid fuel prices would effectively contribute to a changeover, and Kölbl et al. (2013) identified energy cost gains together with purchase price as the variables setting the threshold in favour (or not) of cleaner alternatives.

In the case of the hybrid alternative, its price causes the highest elasticity of demand (-2.230). Another two variables with elastic effects on the demand for the hybrid vehicle are its consumption (-2.206) and the range of the combustion vehicle (-1.094). The result for consumption is in line with the operating cost elasticities found for medium fuel efficiencies in the work of McCarthy \& Tay (1998), whereas the value for the conventional (low fuel efficient) vehicle are four times lower in Santander; this suggests that the demand for the traditional alternative is much more stable there.

In the case of electric cars the greatest effects on their demand are due to its purchase price (2.404) and, after the fuel consumption, by the price of the conventional vehicles (1.313), as shown in Table 5.

Finally, it should be remarked that the indirect incentive (in the form of a street parking discount), did not stimulate a high elasticity in the demand for EV. Thus, our results support previous research that concluded that purchase incentives have a greater impact than indirect ones (Diamond, 2009; Potoglou \& Kanaroglou, 2007; Shin et al., 2012; Struben \& Sterman, 2008). 


\section{Simulation of scenarios}

De cara a incrementar la evidencia derivada de los parámetros y elasticidades calculadas, en este apartado se simulan los cambios en las proporciones de mercado que resultarían de la aplicación de varios escenarios. Para ello se ha procedido a modificar las siguientes variables en distintas proporciones: precio de los vehículos, consumo, autonomía, descuento en el aparcamiento en la calle y disponibilidad de puntos de recarga. En la Table 6 se describen los escenarios planteados y las variaciones de mercado obtenidas.

[Table 6. Simulated scenarios of demand for the three vehicle alternatives]

Puede observarse como el escenario de aumento de los costes de consumo $(€ / \mathrm{km})$ en el caso del vehículo tradicional, provocó una significativa reducción en su proporción de mercado (-9.5\%) y un aumento tanto en la elección de vehículo eléctrico como sobre todo de vehículo híbrido.

La reducción de precios de un $25 \%$ en los vehículos Hybrid y Electric es la que produjo un mayor aumento de su proporción de mercado, si bien en la alternativa Hybrid el incremento fue claramente superior al de la alternativa Electric. Estos escenarios indican que la penalización del vehículo tradicional y la reducción de los precios de los environmentally friendly vehicles son las dos medidas de política más efectivas para incentivar el uso de estos últimos. Estos cambios a corto-medio plazo pueden estar impulsados sobre todo por el uso del vehículo híbrido más que por la adopción del vehículo eléctrico. En términos de coste-beneficio seguramente la medida más efectiva sería el incremento de los costes del vehículo convencional ya que permitiría penalizar las externalidades ambientales negativas generadas por este tipo de vehículo a la vez que la recaudación podría invertirse en la promoción de los modos de transporte más sostenibles. Sin embargo, en la práctica puede ser una política con dificultades de implementación debido a su posible impopularidad. Otras medidas como la gratuidad de los vehículos eléctricos para aparcar en la calle o la mayor disponibilidad de puntos de recarga tendrán, según las estimaciones realizadas, únicamente efectos moderados en la mayor adopción del vehículo eléctrico.

\section{Conclusions}

Not only the automobile industry, the providers of energy different than oil and the local authorities, but also society in general, can benefit from an increased demand for alternative fuel vehicles. Moving to such motors would imply a cleaner environment, a more sustainable way of life and more economic independence in countries highly dependent on oil imports. Nevertheless, in spite of over two decades in the market, these new alternatives still do not enjoy any real success. Given that each country and region may show different perceptions about alternative-fuel vehicles, policies established to promote their markets should be studied in detail keeping a local focus to adopt sustainable practices as efficiently as possible.

The goal of our research was bringing to light some questions still existent in the literature and address aspects that had not been considered in previous research. The diversity of results in the literature is probably due to several reasons, such as context, available information, attributes considered, data collection methods, and the specification chosen for the demand models. For this reason, this research gave an important role to citizen involvement since the initial stages of the methodology. A debate between consumers is a useful technique to understand which factors influence their purchasing behaviour, thereby, allowing the design of a SP questionnaire tailored made to the requirements and preoccupations of potential buyers in the city. 
Our model identified some policy priorities for stimulating demand for hybrid and electric vehicles in the city of Santander (Spain), being both products practically non-existent in Spain today. However, as indicated by Bunch et al. (1993) it is important to be careful when interpreting predictions under SP choice scenarios because these introduce hypothetical rather than existing situations, where the choices stated by individuals may not correspond to what would be their decisions in real life. Therefore, the applied methodology only serves to examine behaviour under a hypothetical future market.

With respect to modelling, this research emphasised the need to consider variability in consumer tastes in order to guarantee the success of potential promotion strategies for new alternative vehicles in Santander. As Jaffe and Stavins (1994) pointed out, one of the weak points in the market for alternatives to petrol-powered vehicles resides in being able to correctly consider heterogeneity among the population.

Our results show two specific priorities for the promotion of cleaner alternative vehicles, especially hybrid cars, in the case of Santander. Firstly, an important predictable impact on the demand for alternative fuel vehicles would be obtained through penalising traditional petrolpowered engines. This effect would be even stronger on those individuals who planned to buy a new vehicle within the next three years. This conclusion partly answers the question regarding which strategy should administrations follow; it appears that for our sample, the penalization of the conventional vehicle should yield a significant impact. While the price of fuel depend partly on diplomacy and international relationships, direct taxes based on annual kilometres or petroleum fuel can be expected to stimulate the uptake of cleaner options. Thus, a complementary policy should incentive the development of significantly more efficient hybrid engines than their purely combustion counterparts.

The second priority for increasing the demand for cleaner vehicles in Santander should aim at enhancing the competitiveness of their prices. Therefore, as previously shown by Diamond (2009) and Gallagher and Muehlegger (2011) among others, any incentives should give priority to the reduction of purchase price or of the taxes directly associated with the purchase, or with the circulation of cleaner vehicles.

A clear inelasticity appears to exist in the demand for traditional combustion vehicles. The reasons argued by Ahn et al. (2008) may explain this, that is, the dominant market position of the petrol car is due to the stability of its supply, existing infrastructure and available maintenance network.

On the other hand, the hybrid alternative receives significant elasticity both direct and crossed, due to changes in its attributes and of those characterising the conventional car (e.g. price, consumption). The model also shows that the hybrid alternative is an attractive possibility for individuals who stated they would contemplate buying a new car in the longer term. The estimated parameters and the analysis of demand elasticities suggest that hybrid vehicles would be perceived as an attractive option in Santander, with a consequent increase in market shares.

Furthermore, households planning to buy a car within the next three years perceive petrol costs more negatively than the rest, increasing their likelihood to opt for the cleanest alternatives, especially for hybrids. Also, those that would need to buy a vehicle in the longer term (more than five years) find a higher utility in the hybrid alternative than the rest of the consumers. Consequently, the prediction of future demand in Santander is clearly in favour of the hybrid option; the electric alternative should only appear on a step further. However, this contrasts with the conclusions drawn by Shin et al. (2012), who identified the potential for EV to be greater than that of hybrids and petrol engines in South Korea. In any case, the initial penetration of hybrid engines could actually stimulate an increase in the utility of the fully electric option, since the 
gradual presence of greener engines will reduce the existent uncertainty regarding the performance and potential of new vehicles, as claimed in the literature (Jaffe and Stavins, 1994; Kurani et al., 1996; Struben and Sterman, 2008; Jensen et al., 2013).

An important point that has been revealed in our work is that range, in itself, does not have such a strong effect as some of the aspects mentioned above, and turned out to be a factor perceived in a highly heterogeneous way. Thus, in line with several authors (Greaves et al., 2014; Kölbl et al., 2013; Kurani et al., 1996) we conclude that range is not always decisive due to usage patterns and the fact that vehicles tend to be parked most of the time. Notwithstanding, our research identified two factors that indirectly give importance to the range. Firstly, we found significant correlation between the perception of the prices of electric motors and fuel engines and their ranges. Secondly, evidence was also found that the preference for EV is smaller for people that do not know whether there are battery recharging points nearby their homes, evoking the so-called range anxiety.

A final conclusion can be drawn from this research: work needs to be done on eliminating uncertainty by providing information about the characteristics of hybrid and electric vehicles, and on creating an adequate recharging network infrastructure. An initial strategy could be to push forward the use of hybrid and electric vehicles through the renewal of the vehicle fleets providing public services (such as public transport and taxis), waste collection vehicles and cars used exclusively by public service employees, with hybrid or electric alternatives. This would indirectly improve the administrations' public image (Gao and Kitirattragarn, 2008) and encourage the adoption of cleaner vehicles by the general public.

Finally, as evidenced in previous studies, drivers adjust their perceptions about new products once they have experienced them (Bühler et al., 2014; Jensen et al., 2014; Mau et al., 2008); so, the market share for cleaner vehicles should be expected to gradually increase, making it possible to compare revealed preference studies with predictions based on the currently more common stated preference data.

\section{ACKNOWLEDGEMENTS}

To thank the Institute in Complex Engineering Systems (ICM: P-05-004-F; CONICYT: FBO16), the Centre for Sustainable Urban Development, CEDEUS (Conicyt/Fondap/15110020) and the Bus Rapid Transit Centre of Excellence funded by VREF (www.brt.cl), for their support.

\section{REFERENCES}

Adler, T., Wargelin, L., Kostyniuk, L. P., Kavalec, C. \& Occhiuzzo, G. (2003). Incentives for alternate fuel vehicles: a large-scale stated preference experiment. In Proceedings of the 10th International Conference on Travel Behaviour Research, August 10-15. Lucerne.

Ahn, J., Jeong, G. \& Kim, Y. (2008). A forecast of household ownership and use of alternative fuel vehicles: a multiple discrete-continuous choice approach. Energy Economics, 30, 2091-2104.

Axsen, J. \& Kurani, K.S. (2012). Who can recharge a plug-in electric vehicle at home? Transportation Research, 17D, 349-353. 
Axsen, J., Mountain, D. C. \& Jaccard, M. (2009). Combining stated and revealed choice research to simulate the neighbor effect: the case of hybrid-electric vehicles. Resource and Energy Economics, 31, 221-238.

Beggs, S., Cardell, S. \& Hausman, J. (1981). Assessing the potential demand for electric cars. Journal of Econometrics, 17, 1-19.

Bolduc, D., Boucher, N. \& Alvarez-Daziano, R. (2008). Hybrid choice modeling of new technologies for car choice in Canada. Transportation Research Record, 2082, 63-71.

Brownstone, D. \& Train, K. (1999). Forecasting new product penetration with flexible substitution patterns. Journal of Econometrics, 89, 109-129.

Brownstone, D., Bunch, D.S. \& Train, K. (2000). Joint mixed logit models of stated and revealed preferences for alternative-fuel vehicles. Transportation Research, 34b, 315-338.

Brownstone, D., Bunch, D.S., Golob, T.F. \& Ren, W. (1996). A transactions choice model for forecasting demand for alternative-fuel vehicles. Research in Transportation Economics, 4, 87-129.

Bühler, F., Cocron, P., Neumann, I., Franke, T. \& Krems, J.F. (2014). Is EV experience related to EV acceptance? Results from a German field study. Transportation Research 25F, 34-49.

Calfee, J. E. (1985). Estimating the demand for electric automobiles using fully disaggregated probabilistic choice analysis. Transportation Research, 19B, 287-301.

Choo, S. \& Mokhtarian, P. L. (2004). What type of vehicle do people drive? The role of attitude and lifestyle in influencing vehicle type choice. Transportation Research 38A, 201-222.

Dagsvik, J.K., Wennemo, T., Wetterwald, D.G. \& Aaberge, R. (2002). Potential demand for alternative fuel vehicles. Transportation Research, 36B, 361-384.

Daziano, R.A. \& Chiew, E. (2012). Electric vehicles rising from the dead: data needs for forecasting consumer response toward sustainable energy sources in personal transportation. Energy Policy, 51, 876-894.

Daziano, R.A. \& Chiew, E. (2013). On the effect of the prior of Bayes estimators of the willingness to pay for electric-vehicle driving range. Transportation Research, 21D, 7-13.

Diamond, D. (2009). The impact of government incentives for hybrid-electric vehicles: evidence from US states. Energy Policy, 37, 972-983.

Dimitropoulos, A., Rietveld, P. \& van Ommeren, J.N. (2013). Consumer valuation of changes in driving range: a meta-analysis. Transportation Research, 55A, 27-45.

Ewing, G.O. \& Sarigöllü, E. (1998). Car fuel-type choice under travel demand management and economic incentives. Transportation Research, 3D, 429-444.

Francisco, J.B.-B., Tibor, H. (2015) The Potential of Electromobility in Austria: An Analysis Based on Hybrid Choice Models. Transportation Research Part A: Policy and Practice (In Press).

Franke, T. \& Krems, J.F. (2013). What drives range preferences in electric vehicle users? Transport Policy, 30, 56-62.

Gallagher, K.S. \& Muehlegger, E. (2011). Giving green to get green? Incentives and consumer adoption of hybrid vehicle technology. Journal of Environmental Economics and Management, 61, 1-15. 
Gao, H.O. \& Kitirattragarn, V. (2008). Taxi owners' buying preferences of hybrid-electric vehicles and their implications for emissions in New York City. Transportation Research, 42A, 10641073.

Gould, J. \& Golob, T.F. (1998). Clean air forever? A longitudinal analysis of opinions about air pollution and electric vehicles. Transportation Research, 3D, 157-169.

Graham-Rowe, E., Gardner, B., Abraham, C., Skippon, S., Dittmar, H., Hutchins, R. \& Stannard, J. (2012). Mainstream consumers driving plug-in battery-electric and plug-in hybrid electric cars: a qualitative analysis of responses and evaluations. Transportation Research, 46A, 140153.

Greaves, S., Backman, H. \& Ellison, A.B. (2014). An empirical assessment of the feasibility of battery electric vehicles for day-to-day driving. Transportation Research, 66A, 226-237.

Greene, W.H. (2007). NLOGIT version 4.0: Reference guide. Econometric Software, Australia.

Greene, W.H., Hensher, D.A. \& Rose, J.M. (2006). Accounting for heterogeneity in the variance of unobserved effects in mixed logit models. Transportation Research, 40B, 75-92.

He, L., Chen, W. \& Conzelmann, G. (2012). Impact of vehicle usage on consumer choice of hybrid electric vehicles. Transportation Research, 17D, 208-214.

Heffner, R.R., Kurani, K.S. \& Turrentine, T.S. (2007). Symbolism in California's early market for hybrid electric vehicles. Transportation Research, 12D, 396-413.

Hensher DA, Rose JM, Greene WH (2015) Applied Choice Analysis. Second Edition. Cambridge

Hidrue, M.K., Parsons, G.R., Kempton, W. \& Gardner, M.P. (2011). Willingness to pay for electric vehicles and their attributes. Resource and Energy Economics, 33, 686-705.

Hoen, A. \& Koetse, M.J. (2014). A choice experiment on alternative fuel vehicle preferences of private car owners in the Netherlands. Transportation Research, 61A, 199-215.

Horne, M., Jaccard, M. \& Tiedemann, K. (2005). Improving behavioral realism in hybrid energyeconomy models using discrete choice studies of personal transportation decisions. Energy Economics, 27, 59-77.

Ibeas, A., Dell'Olio, L. \& Montequín, R.B. (2011). Citizen involvement in promoting sustainable mobility. Journal of Transport Geography, 19, 475-487.

Ito, N., Takeuchi, K. \& Managi, S. (2013). Willingness-to-pay for infrastructure investments for alternative fuel vehicles. Transportation Research, 18D, 1-8.

Jaffe, A.B. \& Stavins, R.N. (1994). Energy-efficiency investments and public policy. The Energy Journal, 15, 43-64.

Jensen, A.F., Cherchi, E. \& Mabit, S.L. (2013). On the stability of preferences and attitudes before and after experiencing an electric vehicle. Transportation Research, 25D, 24-32.

Jensen, A.F., Cherchi, E. \& Ortúzar, J. de D. (2014). A long panel survey to elicit preferences for electric vehicles. Transportation, 41, 973-993.

Jones, L.R., Cherry, C.R., Vu, T.A. \& Nguyen, Q.N. (2013). The effect of incentives and technology on the adoption of electric motorcycles: a stated choice experiment in Vietnam. Transportation Research, 57A, 1-11. 
Karplus, V.J., Paltsev, S. \& Reilly, J.M. (2010). Prospects for plug-in hybrid electric vehicles in the United States and Japan: a general equilibrium analysis. Transportation Research, 44A, 620641.

Kölbl, R., Bauer, D. \& Rudloff, C. (2013). Travel behaviour and electric mobility in Germany. Transportation Research Record, 2385, 45-52.

Kurani, S., Turrentine, T. \& Sperling, D. (1996). Testing electric vehicle demand in "hybrid households" using a reflexive survey. Transportation Research, 1C, 131-150.

Lebeau, K., Van Mierlo, J., Lebeau, P., Mairesse, O. \& Macharis, C. (2012). The market potential for plug-in hybrid and battery electric vehicles in Flanders: a choice-based conjoint analysis. Transportation Research, 17D, 592-597.

Li, X., Clark, C.D., Jensen, K.L., Yen, S.T. \& English, B.C. (2013). Consumer purchase intentions for flexible-fuel and hybrid-electric vehicles. Transportation Research, 18D, 9-15.

Lin, Z., \& Greene, D.L. (2010). A plug-in hybrid consumer choice model with detailed market segmentation. 89th Annual Meeting of the Transportation Research Board, Washington D.C.

Mau, P., Eyzaguirre, J., Jaccard, M., Collins-Dodd, C. \& Tiedemann, K. (2008). The "neighbor effect": simulating dynamics in consumer preferences for new vehicle technologies. Ecological Economics, 68, 504-516.

McCarthy, P.S. \& Tay, R.S. (1998). New vehicle consumption and fuel efficiency: a nested logit approach. Transportation Research, 34E, 39-51.

Musti, S. \& Kockelman, K.M. (2011). Evolution of the household vehicle fleet: anticipating fleet composition, PHEV adoption and GHG emissions in Austin, Texas. Transportation Research, 45A, 707-720.

Nunes B, Bennett D (2010) Green operations initiatives in the automotive industry: An environmental reports analysis and benchmarking study Benchmarking: An International Journal 17:396-420 doi:doi:10.1108/14635771011049362

Ortúzar, J. de D. \& Willumsen, L.G. (2011). Modelling Transport. Fourth edition. John Wiley \& Sons, Chichester.

Paul, B.M., Kockelman, K.M. \& Musti, S. (2011). Evolution of the light-duty vehicle fleet. Transportation Research Record, 2252, 107-117.

Plötz, P., Schneider, U., Globisch, J. \& Dütschke, E. (2014). Who will buy electric vehicles? Identifying early adopters in Germany. Transportation Research, 67A, 96-109.

Potoglou, D. \& Kanaroglou, P.S. (2007). Household demand and willingness to pay for clean vehicles. Transportation Research, 12D, 264-274.

Rea, L.M., Parker, R.A. (2014) Designing and conducting survey research: A comprehensive guide. John Wiley \& Sons.

Regan, M.A., Labeye, E., Brusque, C., Hugot, M. \& Adrian, J. (2013). Daily use of an electric vehicle: behavioural changes and potential for ITS support. IET Intelligent Transport Systems, 7, 210214.

Rezvani, Z., Jansson, J. \& Bodin, J. (2015). Advances in consumer electric vehicle adoption research: a review and research agenda. Transportation Research, 34D, 122-136.

Rose, J.M. \& Bliemer, M.C.J. (2009). Constructing efficient stated choice experimental designs. Transport Reviews, 29, 587-617. 
Shepherd, S., Bonsall, P. \& Harrison, G. (2012). Factors affecting future demand for electric vehicles: a model based study. Transport Policy, 20, 62-74.

Shin, J., Hong, J., Jeong, G. \& Lee, J. (2012). Impact of electric vehicles on existing car usage: a mixed multiple discrete - continuous extreme value model approach. Transportation Research 17D, 138-144.

Sierzchula, W. (2014). Factors influencing fleet manager adoption of electric vehicles. Transportation Research, 31D, 126-134.

Stark J, Link C, Simic D, Bäuml T (2015) Required range of electric vehicles - an analysis of longitudinal mobility data. IET Intelligent Transport Systems 9:119-127

Stark, J., Link, C., Simic, D., Bäuml, T. (2015) Required range of electric vehicles - an analysis of longitudinal mobility data. IET Intelligent Transport Systems. Institution of Engineering and Technology, pp. 119-127.

Steinhilber S, Wells P, Thankappan S (2013) Socio-technical inertia: Understanding the barriers to electric vehicles Energy Policy 60:531-539 doi:http://dx.doi.org/10.1016/j.enpol.2013.04.076

Steinhilber, S., Wells, P., Thankappan, S. (2013) Socio-technical inertia: Understanding the barriers to electric vehicles. Energy Policy 60, 531-539.

Struben, J. \& Sterman, J.D. (2008). Transition challenges for alternative fuel vehicle and transportation systems. Environment and Planning, 35B, 1070-1097.

Tamor MA, Moraal PE, Reprogle B, Milačić M (2015) Rapid estimation of electric vehicle acceptance using a general description of driving patterns Transportation Research Part C: Emerging Technologies 51:136-148 doi:http://dx.doi.org/10.1016/j.trc.2014.10.010

Tamor, M.A., Moraal, P.E., Reprogle, B., Milačić, M. (2015) Rapid estimation of electric vehicle acceptance using a general description of driving patterns. Transportation Research Part C: Emerging Technologies 51, 136-148.

Tanaka, M., Ida, T., Murakami, K. \& Friedman, L. (2014). Consumers' willingness to pay for alternative fuel vehicles: a comparative discrete choice analysis between the US and Japan. Transportation Research, 70A, 194-209.

Taylor, P., Daziano, R.A. \& Bolduc, D. (2013). Incorporating pro-environmental preferences towards green automobile technologies through a Bayesian hybrid choice model. Transportmetrica 9A, 74-106.

Tessum CW, Hill JD, Marshall JD (2014) Life cycle air quality impacts of conventional and alternative light-duty transportation in the United States Proceedings of the National Academy of Sciences 111:18490-18495 doi:10.1073/pnas.1406853111

Tessum, C.W., Hill, J.D., Marshall, J.D. (2014) Life cycle air quality impacts of conventional and alternative light-duty transportation in the United States. Proceedings of the National Academy of Sciences 111, 18490-18495.

Train, K. (2009). Discrete Choice Methods with Simulation. Second edition. Cambridge University Press, Cambridge.

Turrentine, T.S. \& Kurani, K.S. (2007). Car buyers and fuel economy? Energy Policy, 35, 1213-1223.

van Rijnsoever FJ, Hagen P, Willems M (2013) Preferences for alternative fuel vehicles by Dutch local governments Transportation Research Part D: Transport and Environment 20:15-20 doi:http://dx.doi.org/10.1016/j.trd.2013.01.005 
Walker, J.L., Ben-Akiva, M. \& Bolduc, D. (2007). Identification of parameters in normal error component logit-mixture (NECLM) models. Journal of Applied Econometrics, 22, 1095-1125.

Zapata C, Nieuwenhuis P (2010) Exploring innovation in the automotive industry: new technologies for cleaner cars Journal of Cleaner Production 18:14-20 doi:https://doi.org/10.1016/j.jclepro.2009.09.009

Ziegler, A. (2012). Individual characteristics and stated preferences for alternative energy sources and propulsion technologies in vehicles: a discrete choice analysis for Germany. Transportation Research, 46A, 1372-1385. 
Table 1. Attributes describing the alternatives in the SP choice experiment

\begin{tabular}{ccc}
\hline Variable and description & Measure & Alternatives \\
\hline $\begin{array}{c}\text { Price: amount to pay after the discount } \\
\text { (incentive) is applied }\end{array}$ & Euros $(€)$ & $\mathrm{C}, \mathrm{H}, \mathrm{E}$ \\
\hline $\begin{array}{ccc}\text { Incentive: price discount } \\
\text { Consumption: fuel consumption costs }\end{array}$ & Euros $(€)$ & $\mathrm{H}, \mathrm{E}$ \\
\hline $\begin{array}{c}\text { Range: distance the vehicle can travel } \\
\text { without needing to recharge }\end{array}$ & Kilometres $(\mathrm{km})$ & $\mathrm{C}, \mathrm{H}, \mathrm{E}, \mathrm{E}$ \\
\hline $\mathrm{E}$ parking discount & Percentage over the fee $(\%)$ & $\mathrm{E}$ \\
\hline $\begin{array}{c}\text { Availability of recharging points in the area } \\
\text { around the house }\end{array}$ & Available (1) or not (0) & $\mathrm{E}$ \\
\hline
\end{tabular}


Table 2. Attributes levels in the SP choice experiment for medium sized vehicles

\begin{tabular}{|c|c|c|c|c|c|c|}
\hline $\mathbf{S}$ & Alternative & Price $(€)$ & $\begin{array}{c}\text { Consumption } \\
(€ / 100 \mathrm{~km})\end{array}$ & $\begin{array}{c}\text { Street } \\
\text { Parking } \\
\text { Discount (\%) }\end{array}$ & Range (km) & $\begin{array}{l}\text { Availability recharging } \\
\text { points }\end{array}$ \\
\hline \multirow{3}{*}{1} & Combustion & 12500 & 5.7 & 0 & 1700 & 0 \\
\hline & Hybrid & 20250 & 4.9 & 0 & 1500 & 0 \\
\hline & Electric & 18700 & 1.5 & 100 & 600 & There are enough \\
\hline \multirow{3}{*}{2} & Combustion & 15500 & 4.2 & 0 & 1400 & 0 \\
\hline & Hybrid & 18250 & 5.4 & 0 & 1800 & 0 \\
\hline & Electric & 21250 & 1.8 & 20 & 200 & There are enough \\
\hline \multirow{3}{*}{3} & Combustion & 17000 & 4.2 & 0 & 1700 & 0 \\
\hline & Hybrid & 24700 & 5.4 & 0 & 1400 & 0 \\
\hline & Electric & 23750 & 1.2 & 50 & 200 & There are not enough \\
\hline \multirow{3}{*}{4} & Combustion & 14000 & 6.2 & 0 & 1700 & 0 \\
\hline & Hybrid & 21350 & 4.9 & 0 & 1500 & 0 \\
\hline & Electric & 21250 & 1.2 & 20 & 800 & There are enough \\
\hline \multirow{3}{*}{5} & Combustion & 15500 & 5.7 & 0 & 1400 & 0 \\
\hline & Hybrid & 17150 & 3.9 & 0 & 1700 & 0 \\
\hline & Electric & 25000 & 1.5 & 100 & 400 & There are enough \\
\hline \multirow{3}{*}{6} & Combustion & 14000 & 5.2 & 0 & 1400 & 0 \\
\hline & Hybrid & 25800 & 3.9 & 0 & 1800 & 0 \\
\hline & Electric & 20000 & 1.8 & 30 & 400 & There are not enough \\
\hline \multirow{3}{*}{7} & Combustion & 17000 & 6.2 & 0 & 1400 & 0 \\
\hline & Hybrid & 20400 & 5.9 & 0 & 1400 & 0 \\
\hline & Electric & 14950 & 1.7 & 50 & 600 & There are not enough \\
\hline \multirow{3}{*}{8} & Combustion & 12500 & 5.2 & 0 & 1700 & 0 \\
\hline & Hybrid & 19300 & 5.9 & 0 & 1700 & 0 \\
\hline & Electric & 27500 & 1.7 & 30 & 800 & There are not enough \\
\hline
\end{tabular}


Table 3. Distribution of observations in the sample

\begin{tabular}{|c|c|c|}
\hline & & Percentage \\
\hline Gender & Female & 36.0 \\
\hline \multirow{6}{*}{ Age } & 24 or younger & 1.7 \\
\hline & 25 to 34 years old & 13.3 \\
\hline & 35 to 44 years old & 18.8 \\
\hline & 45 to 54 years old & 28.2 \\
\hline & 55 to 64 years old & 18.2 \\
\hline & 65 or older & 19.9 \\
\hline \multirow{4}{*}{ Household members } & 1 & 30.9 \\
\hline & 2 & 40.9 \\
\hline & 3 & 20.5 \\
\hline & 4 & 7.7 \\
\hline \multirow{4}{*}{ Monthly household income } & $\leq 1000 €$ & 24.1 \\
\hline & $1000-2500 €$ & 54.3 \\
\hline & $2500-5000 €$ & 17.3 \\
\hline & $>5000 €$ & 4.3 \\
\hline \multirow{5}{*}{ Number of cars } & None, but willing to purchase & 3.3 \\
\hline & 1 & 80.7 \\
\hline & 2 & 12.7 \\
\hline & 3 & 2.2 \\
\hline & 4 & 1.1 \\
\hline \multirow{3}{*}{$\begin{array}{l}\text { Are there any recharging points in the } \\
\text { area around the household? }\end{array}$} & Yes & 6.7 \\
\hline & No & 71.3 \\
\hline & Do not know & 22.1 \\
\hline \multirow{4}{*}{ When are you going to buy a new car? } & Within the next three years & 10 \\
\hline & Within three and five years & 9.4 \\
\hline & In more than five years & 44.5 \\
\hline & Do not know & 36.1 \\
\hline \multirow{2}{*}{ Vehicle size in the next purchase } & Medium - urban & 71.3 \\
\hline & Large & 28.7 \\
\hline \multirow{4}{*}{$\begin{array}{l}\text { Parking situation of current vehicle that } \\
\text { will be the next to replace }\end{array}$} & Garage at home & 38.9 \\
\hline & Garage near home & 17.2 \\
\hline & Free street parking & 35.6 \\
\hline & Reserved parking & 8.3 \\
\hline \multirow{5}{*}{$\begin{array}{l}\text { Use made of current vehicle that will be } \\
\text { the next to replace }\end{array}$} & Exclusively urban use & 8.3 \\
\hline & Mostly urban use & 31.1 \\
\hline & Mixed urban-interurban use & 42.2 \\
\hline & Mostly interurban use & 15 \\
\hline & Exclusively interurban use & 3.3 \\
\hline \multirow{4}{*}{$\begin{array}{l}\text { Frequency of use of current vehicle that } \\
\text { will be the next to replace }\end{array}$} & Daily use (all day travel to work) & 24.4 \\
\hline & Daily use & 41.1 \\
\hline & Weekly use & 30 \\
\hline & Monthly use & 4.4 \\
\hline
\end{tabular}


Table 4. Estimated parameters describing purchase choice

\begin{tabular}{|c|c|c|}
\hline Variable (alternative where it enters) & Coefficient & t-test \\
\hline \multicolumn{3}{|l|}{ Non-random parameters } \\
\hline Constant (Combustion) & 7.121 & 5.374 \\
\hline Consumption (Combustion, Hybrid) & -0.762 & -8.176 \\
\hline $\begin{array}{l}\text { Proposed change of car in less than } 3 \text { years*Consumption } \\
\text { (Combustion) }\end{array}$ & -0.330 & -2.559 \\
\hline Constant (Hybrid) & 7.110 & 10.366 \\
\hline Proposed change of car over 5 years (Hybrid) & 0.853 & 2.087 \\
\hline Street parking discount (Electric) & $1.437 \mathrm{D}-02$ & 2.819 \\
\hline Availability of recharging points (Electric) & 1.681 & 6.209 \\
\hline $\begin{array}{c}\text { Not knowing if there are recharging points in area around } \\
\text { home address (Electric) }\end{array}$ & -1.490 & -2.120 \\
\hline \multicolumn{3}{|l|}{ Random parameters } \\
\hline Range (Combustion, Electric) & $2.011 \mathrm{D}-03$ & 2.578 \\
\hline Price (Combustion, Hybrid, Electric) & $-2.928 \mathrm{D}-04$ & -9.307 \\
\hline \multicolumn{3}{|c|}{ Diagonal values in Cholesky matrix } \\
\hline Range (Combustion, Electric) & $6.223 \mathrm{D}-04$ & 2.032 \\
\hline Price (Combustion, Hybrid, Electric) & $9.065 \mathrm{D}-05$ & 0.068 \\
\hline \multicolumn{3}{|c|}{ Below diagonal values in Cholesky matrix } \\
\hline $\begin{array}{c}\text { Price (Combustion, Hybrid, Electric) - Range (Combustion, } \\
\text { Electric) }\end{array}$ & $1.483 \mathrm{D}-04$ & 3.551 \\
\hline \multicolumn{3}{|c|}{ Standard deviations of latent random effects } \\
\hline EC (Combustion - Hybrid) & 2.153 & 5.821 \\
\hline EC (Hybrid - Electric) & 2.297 & 6.460 \\
\hline EC (Combustion - Electric) & 0.339 & 0.314 \\
\hline \multicolumn{3}{|c|}{ Standard deviations of parameter distributions } \\
\hline Range (Combustion, Electric) & $6.223 \mathrm{D}-04$ & 2.032 \\
\hline Price (Combustion, Hybrid, Electric) & $1.486 \mathrm{D}-04$ & 4.004 \\
\hline Log likelihood value & & -704.292 \\
\hline Restricted log likelihood & & -1532.564 \\
\hline McFadden's Pseudo R² (No coefficients) & & 0.54 \\
\hline McFadden's Pseudo R2 (Constants only) & & 0.33 \\
\hline $\mathrm{N}$ & & 1448 \\
\hline
\end{tabular}


Table 5. Elasticities of demand for the three vehicle alternatives

\begin{tabular}{|c|c|c|c|}
\hline Variable (Direct demand elasticity) & Combustion & Hybrid & Electric \\
\hline Range (Combustion) & 0.354 & -1.094 & -0.929 \\
Range (Electric) & -0.051 & -0.100 & 0.430 \\
Price (Combustion) & -0.603 & 1.537 & 1.313 \\
Price (Hybrid) & 0.390 & -2.230 & 0.622 \\
Price (Electric) & 0.219 & 0.395 & -2.404 \\
Consumption (Combustion) & -0.572 & 1.748 & 1.418 \\
Consumption (Hybrid) & 0.326 & -2.206 & 0.804 \\
Street parking discount (Electric) & -0.034 & -0.087 & 0.386 \\
Availability of recharging points (Electric) & -0.038 & -0.104 & 0.445 \\
Proposed change of car in less than 3 & -0.036 & 0.058 & 0.045 \\
years*Consumption (Combustion) & -0.037 & 0.192 & -0.091 \\
Proposed change of car in more than 5 years (Hybrid) & 0.008 & 0.023 & -0.213 \\
Not knowing if there is any recharging point in the & & & \\
surroundings of the home address (Electric) & &
\end{tabular}


Table 6. Simulated scenarios of demand for the three vehicle alternatives

\begin{tabular}{|c|c|c|c|}
\hline Scenario & Combustion & Hybrid & Electric \\
\hline Increased Consumption (+25\%) (Combustion) & $-9.5 \%$ & $+6.0 \%$ & $+3.5 \%$ \\
Reduction of price (-25\%) (Hybrid) & $-10.0 \%$ & $+12.3 \%$ & $-2.3 \%$ \\
Reduction of Consumption (-25\%) (Hybrid) & $-6.0 \%$ & $+7.4 \%$ & $-1.4 \%$ \\
Reduction of price (-25\%) (Electric) & $-5.2 \%$ & $-2.4 \%$ & $+7.6 \%$ \\
Increased Autonomy (+50\%) (Electric) & $-2.0 \%$ & $-0.7 \%$ & $+2.7 \%$ \\
Street parking discount (100\%) (Electric) & $-2.4 \%$ & $-0.8 \%$ & $+3.2 \%$ \\
Enough availability of recharging points (Electric) & $-2.9 \%$ & $-0.8 \%$ & $+3.7 \%$ \\
\hline
\end{tabular}

